İşletme Akademisi Dergisi
2020, 1 (2): 143-161
DOI:10.26777/TR 1010.2020 .437
Dergi web sayfasi: www.sakder.org

Araștirma Makalesi

\title{
Bankacılık Bölümü Öğrencilerinin Ekonomi Okuryazarlık Düzeyleri Üzerine Bir Araştırma: Nevşehir Hacı Bektaş Veli Üniversitesi Örneği ${ }^{1}$
}

\section{Mehmet KIRAL}

Anadolu Üniversitesi

mehmet.kiral@vakifbank.com.tr,www.orcid.org/0000-0001-7961-0415

Öz

Bu çalışmanın amacı, Nevşehir Hacı Bektaş Veli Üniversitesi İïBF'de ekonomi eğitimi alan Bankacılık Bölümü öğrencilerinin ekonomi okuryazarlık düzeyinin belirlenmesidir. Araştırmada katılımcıların ekonomi okuryazarlık düzeyleri "ekonomi bilgisi", "ekonomik akılcılık", "toplumsal ekonomik yansımalar" ve bireysel ekonomi planlama" boyutlarında incelenmiştir. Araştırmada veri toplama yöntemi olarak anket tekniği kullanılmıştır.

Araştırmada üniversite öğrencilerinin ekonomi okuryazarlık düzeylerini ortaya koyan ifadelerin güvenilirlik düzeylerini ortaya koymak amacıyla Cronbach's Alpha katsayısına bakılmış ve bu değer ölçeğin toplamı için 0,96 olarak tespit edilmiştir. Araştırma için dört hipotez belirlenmiş ve hipotezlerin doğruluğunu test etmek için Mann-Whitney U testi ve Kruskal Wallis H testi uygulanmıştır.

Sonuç olarak, Bankacılık bölümü öğrencilerinin ekonomi okuryazarlık düzeyleri ile cinsiyet, sınıf, herhangi bir yerde çalışma ve kredi kartı kullanma durumu arasında anlamlı bir farklılık ve birinci sınıfta okuyan öğrencilerin ekonomi bilgisini ortaya koyan görüşleri ile dördüncü sınıfta okuyan öğrencilerin görüşleri arasında anlamlı bir farklılık olduğu ortaya çıkmıştır.

Anahtar Kelimeler: Ekonomi Okuryazarlık, Ekonomi Bilgisi, Ekonomik Akılcllık, Bankacılık Eğitimi.

Makale Gönderme Tarihi: 02.03.2020

Makale Kabul Tarihi: 01.05.2020

${ }^{1}$ Anadolu Üniversitesi, Sosyal Bilimler Enstitüsü, Bankacılık ve Finans Bilim Dalı Tezsiz Yüksek Lisans programı dönem bitirme projesi olarak hazırlanmış çalışmadan üretilmiştir.

Önerilen Atıf:

Kıral, M. (2020). Bankacılık Bölümü Öğrencilerinin Ekonomi Okuryazarlık Düzeyleri Üzerine Bir Araştırma: Nevşehir Hacı Bektaş Veli Üniversitesi Örneği, İşletme Akademisi Dergisi, 1(2): 143-161. (C) 2020 İşletme Akademisi Dergisi. 


Journal of Business Academy
$2020,1(2): 143-161$
DOI:10.26677/TR1010.2020.
Web pages: www.isakder.org

Research Article

\title{
A Research on Economics Literacy Level of Banking Department Students: The case of Nevşehir Hacı Bektaş Veli University
}

\section{Mehmet KIRAL}

Anadolu University

mehmet.kiral@vakifbank.com.tr, www.orcid.org/0000-0001-7961-0415

\begin{abstract}
The aim of this study is to determine the economic literacy level of the Banking Department students studying economics. In the study, the level of economic literacy of the participants was examined in the dimensions of bil economic knowledge "," economic rationality "," social economic reflections "and individual economic planning. In the research, questionnaire technique was used as data collection method. The questionnaire was applied to the students of Faculty of Economics and Administrative Sciences at a public university in Ankara.

In this study, Cronbachayiss Alpha coefficient was examined to reveal the reliability levels of the statements that reveal the economic literacy levels of university students and this value was found to be 0.96 for the scale. Four hypotheses were determined for the research and MannWhitney U test and Kruskal Wallis H test were applied to test the accuracy of the hypotheses.

As a result, it was found that there is no significant difference between the level of economic literacy of banking students and gender, class, working anywhere and using credit card. On the other hand, it was found that there was a significant difference between the sub-dimension of economics knowledge and the class variable which revealed the level of economic literacy. In the research, Games-Howell test was used to determine the source of the difference and as a result of the test, it was found that there was a significant difference between the opinions of the first-year students and the fourth-year students.
\end{abstract}

Keywords: Economics Literacy, Economic Knowledge, Economic Rationalism, Banking Education.

Received: 02.03 .2020

Accepted: 01.05.2020

\section{Suggested Citation:}

Kiral, M. (2020). A Research on Economics Literacy Level of Banking Department Students: The case of Nevşehir Hacı Bektaş Veli University, Journal of Business Academy, 1(2): 143-161.

(C) 2020 Journal of Business Academy. 


\section{GİRIŞ}

İktisat; Arapça kökenli "kasıtlı, bilinçli, ılımlı hareket" etmektir ve günlük dilde Türkçeye "tutumluluk" olarak geçmiştir. Ekonomi; eski Yunan kökenli oikia: ev nomos: kural; ev yönetimi anlamındadır. Türk Dil Kurumu (TDK) sözlüğünde kısaca ekonomi; insanların yaşayabilmek adına üretme ve ürettiklerini bölüşme biçimlerinin ve bu eylemlerinden doğan ilişkilerin bütününü inceleyen bilim dalı olarak tanımlanmıştır. En temelde ekonomi tanımı ise; "kaynakların sınırlı, buna karşılık insanoğlunun ihtiyaçlarının sonsuz olması nedeniyle, çeşitli sorulara yanıt arayan bir bilim dalı" şeklindedir (Bilgen ve Çılbant, 2015: 686). Ekonomi bilimi, sınırlı kaynakların sınırsız ihtiyaçlar karşısında etkin dağılımını amaçlamaktadır.

Klasik anlamda okuryazarlığın tanımı ise; "yaşam boyu öğrenme bilincini oluşturma, bu bilinci geliştirme, daha etkin öğrenme için bireylerin yeni beceriler kazanmalarını sağlamaktır" (Aldemir, 2003). Ekonomi okuryazarlığı, ekonomide gerçekleşen gelişmelerin ekonomiye etkilerini yorumlayabilme yeteneği olarak tanımlanabilir. Literatürde birçok çalışmada ekonomi okuryazarlığı ile finansal okuryazarlık aynı çerçevede ele alınmıştır. Ancak ekonomi biliminin, ekonomide gerçekleşen tüm mübadelelerin miktarları ve parasal değerlerini inceleyen bir bilim dalı olması nedeniyle finans sistemini de kapsadığı söylenebilmektedir. Ekonomi okuryazarlığı ve finansal okuryazarlık arasındaki ilişkinin sebebi ekonominin finansal sistemleri de kapsayan bir bilim dalı olmasıdır (Aldemir, 2003).

Küreselleşme neticesinde, finansal piyasaların gelişmesi, ekonomik yapının daha karmaşık hal alması ekonomi okuryazarlı̆̆ını daha da önemli hale getirmiştir. Ekonomi okuryazarlığının olmaması nedeniyle alınan yanlış finansal kararların sadece bireyi değil toplum refahını da olumsuz etkilemesi beklenmektedir (Dilek vd., 2016). Küreselleşen dünyada tüm finansal sistemlerin birbirleriyle uyumlu hale getirilmeye çalışıldı̆̆ sistemlerin geliştiği, yeni yatırım araçlarının çıkartıldığı, yatırım ürünlerinin ve ödeme şekillerinin çeşitlendirildiği ve bir anlamda karmaşıklaştığı görülmektedir. Günümüzde gelişen teknolojinin de etkisiyle bu işlemlerin hız kazanması ile tüm finansal işlemlerin her zaman ve her yerde ulaşılabilirliği söz konusudur. Ekonomi okuryazarlığı sadece finansal sistemlerde işlem yapan işletmeler, kurumlar ve yatırımcıların yeterli seviyede olmasını değil ekonomide yer alan tüm birim ve bireylerin yeterli seviyede olmasını gerektiren bir durum olduğu görülmektedir (Dilek vd., 2016).

Lusardi ve Mitchell (2007) ve Lusardi (2006)'ya göre; ekonomi eğitimi ve temel ekonomi bilgisi bireylerin yatırım, tasarruf, emeklilik planlaması, kredi ve diğer finansal kararlarında önemli rol oynamaktadır (Dilek, 2016: 1867). Tasarrufların yatırıma dönüştürülmesi, yatırımların istihdam ve üretimi artırarak ülke ekonomisine katkı sağlaması, bireylerde ekonomi okuryazarlığı ile gerçekleşecek bir durumdur. Ekonomideki gelişmeleri ve etkilerini belirli bir öngörüyle yorumlayabilen bir birey, doğru kararlar verebilecek, harcamalarını ekonomik şartlara uygun şekilde gerçekleştirebilecek ve tasarruflarını doğru yöneterek daha uygun yatırım araçlarına yönelebilecektir. Bu sayede geleceklerine yönelik alacakları kararlarında daha etkili olabilecekler ve refah seviyelerini artırmış olacaklardır (Lusardi ve Mitchell, 2011).

Günümüz ekonomisini tarihsel süreç olarak ele aldığımızda, hemen hemen on yılda bir ekonomik kriz yaşandığını söyleyebiliriz. 1982 finansal krizi, 1994 krizi, Kasım 2000 ve Şubat 2001 krizleri, 2008 küresel krizi ve son olarak 2018 döviz kurundaki sert yükselişle ekonomide gerçekleşen olumsuz durumu ve etkilerini yorumlayabilme, risklerinin neler olduğunu, olası zararlarını hesap edebilir bir düzeye erişebilme açısından ekonomi okuryazarlığı oldukça önemli bir kavram olarak ortaya çıkmaktadır. Krizlerin oluşmasının öncesinde dünyada gerçekleşen olayları, ekonomideki gelişmeleri, piyasalardaki durumu belirli bir öngörüyle tespit edebilmek ekonomi okuryazarlığının önemini göstermektedir. İşletmeler, kurumlar veya bireyler krizin ne 
zaman patlak vereceğini tahmin edemeyecek olsalar dahi durumu analiz edebilme yeteneği ve tasarrufları doğru finansal araçlara yöneltebilme, yatırım kararlarını bu çerçevede alabilme, risklerden kaynaklanabilecek olası zararlarından korunabilme ya da en aza indirebilmeleri açısından ekonomi okuryazarlığı oldukça önemli bir kavramdır. Ekonomi okuryazarlık düzeyi yüksek bireylerin, işletme ya da kurumların risk yönetiminde de başarılı olacakları düşünülmektedir.

Birbirine entegre olan ulusal ve uluslararası finansal sistemlerindeki menkul kıymet, hisse senedi, tahvil/bono ve diğer çeşitlendirilmiş finansal enstürmanların alım-satım işlemleri teknolojinin de gelişmesiyle her zaman ve her yerden ulaşılabilirliğini mümkün kılmıştır. Bu işlemler, spekülasyon ve manipülasyona açlk haldedir. Ekonomi okuryazar düzeyi yüksek olan kurum, işletme ya da birey, durum analizi yapabilme, gerçekleşebilecek spekülasyona ya da manipülasyona dayalı işlemlere karşı önlem alabilecektir.

Ekonomi okuryazarlığının toplumda kazandırılması açısından eğitiminin, ilkokul müfredatlarında para ve tanımı kavramlarıyla başlayarak verilmesi hatta aile içinde aile bireylerinden edinecekleri basit bilgilerle öğretilmesi suretiyle temel oluşturmasının faydalı olacağı düşünülmektedir.

Bu çalışma Nevşehir Hacı Bektaş Veli Üniversitesi IIİ̈BF'de Bankacılık Bölümü öğrencilerinin ekonomi okuryazarlık düzeylerinin tespit edilmesi ve litaratüre katkı sağlaması amacıyla hazırlanmıştır.

\section{LITERATÜR TARAMASI}

Literatürde finansal okuryazarlık ile ilgili çalışmaların daha fazla olduğu, bunun yanında ekonomi okuryazarlığı ile ilgili bazı çalışmalarında da olduğu görülmüş olup, bu çalışmaların bir kısmına aşağıda yer verilmiştir.

Gerek ve Kurt, (2012) çalışmalarında, yükseköğretim öğrencilerinin ekonomi okuryazarlıklarını belirlemeye yönelik "Ekonomi Okuryazarlığı Ölçeği” geliştirilmesini amaçlamış ve bu amaç doğrultusunda Ekonomi Okuryazarlı̆̆ı Ölçeği'nin geçerliliğini, kapsam geçerliği, ayırt edici geçerlik ve faktör analizi ile belirlemeye çalışmışlardır. Ayırt edici geçerlik çalışması sonucunda ölçekte yer alan 34 maddenin alt grupla üst grubu birbirinden anlamlı düzeyde ayırt ettiği görülmüştür. Faktör analizi sonucunda ölçeğin "Ekonomi bilgisi", "Ekonomik akılcılık", "Toplumsal ekonomik yansımalar" ve "Bireysel ekonomi planlama" olmak üzere dört boyuttan oluşan bir yapı sergilediği sonucuna ulaşmışlardır. Ekonomi Okuryazarlığı Ölçeği'nin geçerlik ve güvenirlik çalışmalarından elde edilen bulgular ölçeğin yükseköğretim öğrencilerinin ekonomi okuryazarlığı düzeylerini geçerli ve güvenilir bir şekilde ölçmek amacıyla kullanılabileceğini ayrıca geliştirilen ölçme aracının yükseköğretimde yer almayan yetişkinlere de uygulanabileceğini vurgulamışlardır.

Mercan vd., (2012) çalışmalarında Ulaştırma Bakanlığı bağlı bir şube çalışanlarına anket uygulamışlardır. Araştırma sonucunda bireysel ekonomi kullanımı boyutunda yüksek düzeyde ekonomi okuryazarı oldukları sonucuna ulaşmışlardır. Ayrıca yapılan analiz sonucunda lise, ve lisans mezunlarına göre yüksek lisans mezunlarının ekonomi okuryazarlık düzeyinin daha yüksek olduğu saptanmıştır. Ekonomi okuryazarlığı alt boyutları ekonomi bilgisi, ekonomik akılcılık, yaş, medeni durum, çalışma süresi, unvan, eğitim, bölüm, cinsiyet ile ekonomi haberlerini takip etme sıklığı ve ekonomi haberlerini merak etme arasında istatistiki olarak anlamlı bir ilişki olduğu bulgusuna ulaşmışlardır.

Akhan, (2013) çalışmasında öğretmenlerin ilköğretim düzeyindeki öğrencilerin Sosyal Bilgiler Derslerindeki ekonomi okuryazarlık düzeylerini artırıcı önerilerde bulunulması amacıyla neler yapabileceğini araştırmıştır. Ekonomi okuryazarı olmanın amacının geleceğin iyi ve etkili 
vatandaşlarına günlük hayatta kullanabilecekleri deneyimler kazandırdığını, özellikle tüketim çılgınlığı yaşanan çağımızda ekonomi eğitiminin, çocukluktan başlayan zorunlu bir eğitim olduğunu belirtmiştir. Ekonomi okuryazarlığ için gerek aile içinde gerekse okullarda verilecek destekleyici derslerin birbiri ile uyumlu olması gerekliliğinden bahsederek bu noktada aile bireyleri ve öğretmenlerin önemini vurgulamıştır. Ekonomi dersi verilirken, öğrencilerin ilkokul çağında oldukları göz önünde bulundurularak daha kolay ve daha zevkli bir şekilde anlatılması gerekliliğinden bahsedilerek öğretmen adaylarının daha fazla ekonomi dersi görmeleri gerektiğini, dersi iktisatçılardan değil Sosyal Bilgiler eğitiminde ekonomi alanında uzmanlaşmış akademisyenlerden almaları ve ekonomi derslerinde yapacakları etkinlikleri uygulama boyutunda öğrenmelerinin faydalı olacağını belirtmiştir.

Wood ve Doyle (2010), yedi büyuik şirkette 1001 çalışanı esas almak üzere ekonomi okuryazarlığ1 üzerine yaptıkları çalışmada, ekonomi okuryazarlığı ile cinsiyet ve gelir artışı arasında pozitif bir ilişki olduğunu göstermişler ve ekonomi okuryazarlığını arttırmak için üniversitelerde ekonomi dersi verilmesinin gerekli olduğunu belirtmişlerdir (Çil Koçyiğit vd. 2018: 220)

Şantaş ve Demirgil, (2015) bir devlet üniversitesinin İktisadi ve İdari Bilimler Fakültesi'nde öğrenim gören 1. ve 4. Sınıf öğrencilerinin ekonomi okuryazarlık düzeyinin saptanmasına yönelik araştırma çalışmalarında; 4. sınıflarda, ekonomi dersi alanlarda ve erkeklerde daha fazla ekonomik ve finansal gelişmeleri takip etme sıkılığının olduğunu saptamışlardır. Ayrıca araştırmaya katılan öğrencilerin; yaş, cinsiyet, eğitim görülen sınıf, eğitim alınan bölüm, ekonomik ve finansal gelişmeleri takip etme sıklığı ve alınan ekonomi dersi sayısının anlamlı farklılıklar oluşturduğunu tespit etmişlerdir. Araştırma sonucunda ulusal ve uluslararası alanda yürütülen çalışmaların genel olarak kişilerin ve öğrencilerin ekonomi okuryazarlık düzeyinin yüksek olmadığını gösterdiğini belirterek, ekonomi okuryazarlığı düzeyinin artırılması amacıyla çeşitli kurs ve programlar düzenlenmesi ve üniversitelerin müfredatlarında ekonomi okuryazarlığına yönelik program ve derslere daha fazla yer verilmesi gerektiğini vurgulamışlardır.

Ünal vd., (2015) ekonomi okuryazarlı̆̆ı üzerine çalışmalarını Dumlupınar Üniversitesi, Tavşanlı Meslek Yüksekokulu'nda kredi kartı kullanan öğrenciler üzerindeki anket çalışmasıyla analiz ve test etmişleridir. Ekonomi okuryazarlığı düzeyi nispi olarak yüksek olan bireylerin, finansal olaylara bakış açısının daha rasyonel ve planlı olduğu, dolayısıyla, bu durumun bireylerin sahip olduğu kredi kartını rasyonel yönde kullanmasını beraberinde getirdiğini belirtmiştir. Çalışmalarında ulaşılan ekonomi okuryazarlık düzeyi yüksek olan bireylerin, kredi kartını daha rasyonel kullanacağı yönündeki sonucun, gerek öngörülerle gerekse literatürdeki diğer mevcut çalışmalarla, ekonomi okuryazarlık seviyesi yükseldikçe, kişinin para ve diğer finansal enstrümanları daha rasyonel kullandığı yönündeki bulgularıyla uyumlu olduğu sonucuna ulaşmışlardır. Ayrıca ekonomi dersini alan üniversite öğrencilerinin, ekonomi okuryazarlığının, söz konusu dersi almayan öğrencilerden daha yüksek olduğu belirtilerek, sahip olunan genel ekonomi bilgisinin ve toplumsal ekonomik yansımaların rasyonel kredi kartı kullanımı üzerinde etkilerinin olmadığı bulgusuna ulaşmıştır.

Dilek vd., (2016) Kastamonu Üniversitesi öğrencilerine yönelik yaptıkları araştırma sonucunda, bireylerin kaynakları daha akılcı kullanarak israftan kaçınmalarının topluma pozitif dışsallık sağlayacağından ekonomi okuryazarlığının önemini ortaya koyacak çalışmaların öneminden bahsetmişlerdir. Üniversite öğrencilerinin sorulara orta ve yüksek değerli cevaplar verdiklerini, sonuç olarak bu öğrencilerin ekonomi okuryazarlı̆̆ 1 konusunda yeterli veya en azından kendilerine güvenini ortaya çıkarttığını ancak ekonomi okuryazarlığı konusunda alacakları mesafe olduğu sonucuna ulaşmışlardır. Ayrıca medeni durum, cinsiyet ve yaş gruplarına göre istatistiki açıdan önemli fark bulunmadığını da tespit etmişlerdir. 
Yıldırım ve Öztürk, (2017) tarafından ekonomi okuryazarlığı ve eğitimi konusunda ekonomi ve sosyal bilgiler eğitimi uzmanları ile sosyal bilgiler öğretmenlerinin görüşlerini belirlemek amacıyla yapılan çalışmada; katılımcılara göre, ekonomi eğitimi için en uygun kademenin ortaöğretim, daha sonra ise ortaokul olduğu, bunu sirasıyla yükseköğretim, ilkokul ve anaokulunun takip ettiği sonucuna ulaşılmıştır.

Barış ve Şeker, (2017) Amasya Üniversitesi Sosyal Bilimler Meslek Yüksek Okulu öğrencilerine yönelik yaptıkları çalışmalarında, ekonomi okuryazarlığının özellikle kariyerlerinin başlarında olan ve önlerinde refah düzeylerini artırmada uzun bir zaman dilimi olan gençler arasındaki öneminden bahsederek ekonomi okuryazarlığının "orta seviyede" olduğunu belirtmişlerdir. Ayrıca cinsiyet değişkeni ile ekonomi bilgisi alt boyutu arasında anlamlı bir farklılık olduğunu ve ekonomi okuryazarlığı düzeylerinin erkek öğrencilerde kız öğrencilere nazaran daha yüksek olduğu bulgusuna ulaşmışlardır. Anketi cevaplayan öğrencilerin ekonomi okuryazarlık düzeyleri öğrenim gördükleri bölüme ve çalışma deneyim durumlarına göre de farklılık gösterdiğini tespit etmişlerdir. Ayrıca elde edilen analizlere göre ekonomik gelişmeleri izledikleri başlıca bilgi kaynakları arasında ilk sırayı ailelerinin aldığını ve bu durumun ekonomi okuryazarlığında eğitimin ilk aşamasının aile olması gerektiği konusunda ipuçları verdiğini belirtmişlerdir. $\mathrm{Bu}$ bağlamda öğrencilerin ekonomi okuryazarlığı düzeylerinin arttırılması eğitiminin ailede başladığını düşünerek, ailelerin ekonomi okuryazarlık düzeyinin yükseltilmesinin de öneminden bahsedilmiş ve aileler için seminer, kurs vb. şekilde eğitim verilmesinin gerekliliği vurgulanmıştır.

Yıldırım, (2017) yaygın eğitim kapsamında çocuklara yönelik olarak ekonomi eğitimi amacıyla yürütülen çalışmaları ve bu çalışmaların örgün eğitime katkısını incelemeyi amaçladığı çalışmasında, nitel araştırma yöntemine uygun olarak web taraması sonucunda tespit edilen yedi programı incelemiştir. Araştırmasında veri toplama tekniği olarak doküman incelemesini kullanmıştır. Elde edilen verilerin analizinde betimsel analiz yaklaşımı kullanmış ve bulguları betimsel olarak sunmuştur. Araştırmada elde edilen sonuçlara göre çocuklara yönelik ekonomi eğitimi çalışmaları bir sivil toplum örgütü ve üç banka tarafından gerçekleştirildiğinden bahisle, programların genel olarak tasarruf bilincini ve bilinçli tüketicilik davranışlarını geliştirmeyi amaçladığını ve çoğunlukla aktif öğrenme yaklaşımına göre tasarlandığını söylemektedir. Yaygın eğitim kapsamında yürütülen programların Hayat Bilgisi ve Sosyal Bilgiler programlarındaki bilinçli tüketicilik ve tasarruf bilincinin geliştirilmesi konusundaki kazanımlara ulaşılmasına katkı sunduğu, bu kazanımlar dışındaki katkısının sınırlı olduğu görülmüştür diyerek çocuklara yönelik ekonomi eğitiminin yaygın eğitim kapsamında yer bulması bu konuda önemli bir girişim olarak değerlendirilmesi gerekliliğinden bahsetmiştir. Ayrıca bu tür çalışmaların toplum geneline yayılarak tasarruf ve para yönetimi etrafında şekillenmemesini, daha da genişletilerek tüketimin ve üretim işlevinin eklenmesini önermiştir.

Demirgil ve Erilli, (2018) çalışmalarında Sıvas halkının ekonomi okuryazarlılığını tespit etmeye çalışmışlardır. Çalışmalarının sonucunda halkın ekonomi okuryazarlığı seviyesinin alt boyut puan ortalamalarının altında gerçekleştiğini belirtmişlerdir. Ekonomi konusunda gerekli eğitimi almayanların genellikle konuları araştırmak yerine internet ve medya sayesinde elde edilen hazır bilgilere yöneldiklerini ve bu durumun doğru bilgi edinmeleri açısından yeterli olmadığ sonucuna varmışlardır. Ekonomi okuryazarlığının yeterli düzeyde olmamasının sonuçlarının, karar birimlerinin tercihlerinde hata yapmalarına ve bunun sonucunda da kıt kaynakların etkin kullanılmadığına neden olduğunu belirterek; ekonomi okuryazarlığı düzeyinin artırılabilmesi için ilgili birimlerce çeşitli kurs, seminer ve programlar düzenlenebilmesinin faydalı olabileceğini öngörmektedirler. Bunun için de Sivas Cumhuriyet Üniversitesi'nin, ekonomi okuryazarlık düzeyinin artırılmasında gerekli destek ve katkıyı sağlayabileceği sonucuna ulaşmışlardır. 
Çil Koçyiğit vd., (2018) Hacı Bayram Veli Üniversitesi Sağlık Yönetimi ve İşletme Bölümü öğrencilerinin ekonomi okuryazarlık düzeylerini tespit edilmesi amacıyla yaptıkları çalışmalarında öğrencilerin, ekonomi okuryazarlık düzeylerinin bazı değişkenlere göre farklılaşıp farklılaşmadığını ortaya koymaya çalışmışlardır. Katılımcıların ekonomi okuryazarlık düzeylerinin tüm alt boyutlar dahil olmak üzere cinsiyet ve bölüm arasında anlamlı bir farklılık olmadığını, sınıflar arasında ise anlamlı farklılık bulunduğunu tespit etmişlerdir. Sınıf düzeyinin artması ile ekonomi okuryazarlık düzeylerinin artmasınının, alınan ekonomi derslerinin sonucu olduğunu ve bu sayede ekonomi okuryazarlık düzeylerinin arttığını belirtmişlerdir. Eğitim ve öğretimin önemli olduğunu, ulusal ve uluslararası çalışmaların, bireylerin ekonomi okuryazarlığına sahip olmalarını ve bu sayede ekonomide doğru kararlar alabilmelerini, dolayısıyla da sınırlı kaynakları etkin biçimde kullanmalarına etki edeceğini vurgulamışlardır. Ekonomi okuryazarlığı düzeyinin arttırılması için, okul müfredatına daha fazla ekonomi okuryazarlık derslerinin veya konularının dahil edilmesini, çeşitli kurs ve programların düzenlenmesinin ve bu uygulamaların tüm toplumu kapsayacak şekilde genişletilmesinin uygun olacağı sonucuna ulaşmışlardır.

Güler ve Veysikarani, (2019) Çukurova Üniversitesi Sosyal Bilimler Enstitüsü lisansüstü öğrencilerinin ekonomi okuryazarlık düzeylerini belirlemeyi hedefleyen çalışmalarında, ekonomi okuryazarlık düzeyini belirlemek için Gerek ve Kurt'un (2011) geçerliliği ve güvenilirliği sınanmış, Türkçe formunu hazırlamış olduğu 34 maddelik ölçeğini kullanılmışlardır. Faktör analizi sonucunda orijinal ölçekten farklı olarak beş alt boyut elde ederek, medeni durum, yaş ve öğrenim seviyesi (doktora öğrencisi veya yüksek lisans öğrencisi olup olmama) demografik değişkenlerinin ekonomi okuryazarlığını etkileme gücünün istatistiksel olarak anlamlı bulunmadığını belirtmişlerdir. Cinsiyet ve geçim kaynağı değişkenlerinin ekonomi okuryazarlık alt boyutları üzerinde istatistiksel bir etkisinin olduğu sonucuna ulaşılmışlardır. Yaptıkları çalışmada elde edilen bulgular ışığında, ekonomi bilmenin veya ekonomi öğrenmenin, eğitim görülen fakülte veya bölüm ile ilişkisinin olmaması, her bölümde eğitim gören öğrencilerin mutlak surette ekonomi hakkında bilgi alması gerekliliğini de vurgulamışlardır. Ayrıca Türkiye'deki farklı yükseköğretim kurumlarında öğrenim gören lisansüstü öğrenciler için benzer çalışmalar yapılarak, ekonomi okuryazarlığı açısından karşılaştırmaların yapılmasının mümkün olabileceğini, böylelikle elde edilecek çalışmaların karşılaştırılarak yorumlanmasının da faydalı olacağını düşünmüşlerdir.

\section{AMAÇ VE YÖNTEM}

Çalışmanın bu kısmında araştırmanın amacı, önemi, araştırmanın yöntemi ve kapsamı, modeli, araştırmanın sınırlılıkları, evreni ve örneklemi, verilerinin analizi aşamaları açıklanmaktadır.

\subsection{Araştırmanın Amacı}

Araştırmanın temel amacı, elde edilen verilerle Nevşehir Hacı Bektaş Veli Üniversitesi İïBBF'de ekonomi eğitimi alan Bankacılık Bölümü öğrencilerinin ekonomi okuryazarlık düzeylerinin incelenmesidir. $\mathrm{Bu}$ kapsamda araştırmada üniversite öğrencilerinin ekonomi okuryazarlık seviyelerini ortaya koyan boyutlar ile demografik özellikleri arasında farklılıkların olup olmadığı araştırılmıştır.

Araştırmada üniversite öğrencilerinin ekonomi okuryazarlık seviyelerinin tespit edilmesine yönelik aşağıdaki hipotezler test edilmiştir:

$\mathrm{H}_{1}$ : Üniversite öğrencilerinin ekonomi okuryazarlık seviyeleri cinsiyetlerine göre anlamlı bir şekilde farklılık göstermektedir.

$\mathrm{H}_{2}$ : Üniversite öğrencilerinin ekonomi okuryazarlık seviyeleri sınıflarına göre anlamlı bir şekilde farklılık göstermektedir. 
$\mathrm{H}_{3}$ : Üniversite öğrencilerinin ekonomi okuryazarlık seviyeleri herhangi bir işte çalışma durumuna göre anlamlı bir şekilde farklılık göstermektedir.

$\mathrm{H}_{4}$ : Üniversite öğrencilerinin ekonomi okuryazarlık seviyeleri kredi kartı kullanma durumuna göre anlamlı bir şekilde farklılık göstermektedir.

\subsection{Araştırmanın Modeli}

$\mathrm{Bu}$ araştırmada betimsel bir tarama modeli kullanılmıştır. Bilindiği üzere tarama modelleri, geçmişte ya da halen varolan bir durumu varolduğu şekliyle betimlemeyi amaçlayan araştırmalara uygun bir modeldir (Yıldız, 2004: 79). Bu araştırmada üniversite öğrencilerinin ekonomi okuryazarlık düzeylerinin cinsiyet, sınıf, herhangi bir işte çalışma durumu ve kredi kartı sahipliğine göre farklılık oluşturup oluşturmadığının tespiti yapılmıştır. Bu yönüyle araştırma betimsel bir tarama modelidir.

Araştırmaya katılan üniversite öğrencilerinin ekonomi okuryazarlık düzeyleri "Ekonomi Bilgisi", "Ekonomik Akılcılık", "Toplumsal Ekonomik Yansımalar" ve "Bireysel Ekonomi Planlama" olmak üzere dört alt boyutta incelenmiştir.

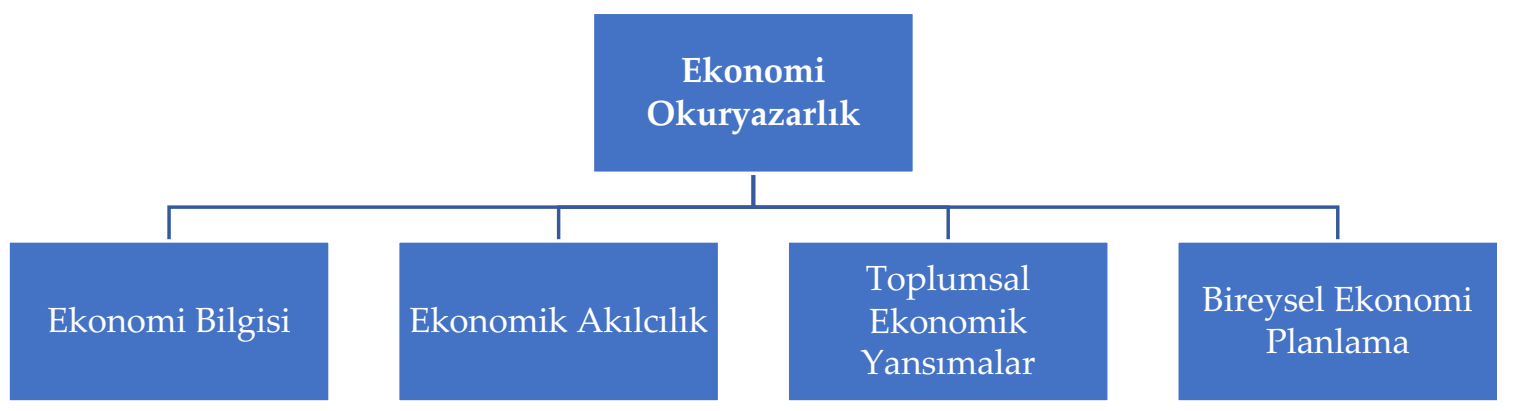

Şekil 1. Ekonomi Okuryazarlık Düzeyi İçerisinde Yer alan Boyutlar

\begin{tabular}{|l|l|}
\hline Cinsiyet & \\
Sınıf & Ekonomi Okuryazarlık \\
Herhangi bir yerde çalışma & Ekonomi Bilgisi \\
Kredi kartı sahipliği & Ekonomik Akılcılık \\
& Toplumsal Ekonomik Yansımalar \\
& Bireysel Ekonomi Planlama \\
\hline
\end{tabular}

Şekil 2. Araştırma Kapsamında Oluşturulan Modeli

\subsection{Verilerin Toplanması}

Çalışmada, verilerin elde edilmesi amacı ile anket yöntemine başvurulmuş olup, Gerek ve Kurt (2011) tarafından geliştirilmiş güvenilirliği ve geçerliliği daha önce saptanmış ekonomi okuryazarlık ölçeği kullanılmıştır. Anket soruları yüz yüze görüşme ile gizlilik esasından hareketle yapılmıştır. Toplam 39 sorudan oluşan anketin birinci bölümde katılımcıların demografik bilgileri, ikinci bölümünde ise katılımcıların ekonomi okuryazarlık düzeylerini ortaya koyan ifadeler yer almaktadır. Uygulama sonucunda elde edilen verilerin çözümlenmesinde paket programdan yararlanılmıştır.

\section{Birinci Bölüm: Kişisel Bilgi Formu}

Bu bölümde ankete katılanların cinsiyet, sınıf, herhangi bir yerde çalışma durumu, lisans eğitimi boyunca alınan dersler ve kredi kartı kullanma durumu ile ilgili bilgiler yer almaktadır. 


\section{İkinci Bölüm: Ekonomi Okuryazarlık Ölçeği}

İkinci bölümde yer alan Ekonomi Okuryazarlık ölçeği 34 sorudan oluşan beşli likert ölçeğidir. Ölçekte yer alan ifadeler;

1. Kesinlikle Katılmıyorum

2. Katılmiyorum

3. Fikrim Yok

4. Kat1liyorum

5. Kesinlikle Katıllyorum

şeklinde derecelendirilmiştir.

\subsection{Araştırmanın Sınırlılıkları ve Varsayımları}

Bu araştırma Nevşehir Hacı Bektaş Veli Üniversitesi İ̈BF'de ekonomi eğitimi alan Bankacılık Bölümünde okuyan öğrencileri kapsamakta olup, yapılacak araştırmanın, öğrencilerin ekonomi okuryazarlık düzeylerini tespit etmeye yönelik yeterli ve güvenilir bilgileri toplayacak nitelikte olacağı düşünülmektedir.

\subsection{Araştırmanın Evreni ve Örneklemi}

Araştırmanın evrenini, Nevşehir Hacı Bektaş Veli Üniversitesi İï̈BF'de ekonomi eğitimi alan Bankacılık bölümü öğrencileri oluşturmaktadır. 2019 yılında sözü edilen bölümde okuyan öğrenci sayıs1 407'dir.

Örneklemi ise, basit tesadüfi örnekleme yöntemi ile seçilen öğrenciler oluşturmaktadır.

$\mathrm{Bu}$ araştırmada istatistiksel açıdan elde edilen verilerin anlamlılık düzeyinin sağlanması amacı ile toplam 215 kişiye anket uygulanmıştır. Ancak, araştırmaya katılanlardan 5 öğrencinin anket formundaki soruların büyük bir kısmını cevaplamadığı görülmüştür. Sonuç olarak, toplam 210 adet anket istatistiksel analize tabi tutulmuştur.

Söz konusu örneklemin yeterli olup olmadığı konusunda ana kütle büyüklüğünün bilindiği durumlarda geçerli olan aşağıdaki formül kullanılmıştır (Yamane, 2001: 116-117).

$\mathrm{n}=$ $\left(\mathrm{Nt}^{2} \mathrm{pq}\right)$

$\left(\mathrm{d}^{2}(\mathrm{~N}-1)+\mathrm{t}^{2} \mathrm{pq}\right)$

$\mathrm{n}=$

$\left(417^{*} 1,96^{2^{*}} 0,10^{*} 0,90\right)$

$\left(0,02^{2 *} 4160+1,96^{2 *} 0,10^{*} 0,90\right)$

$\mathrm{n}=$

Formülde yer alan N: anakütle büyüklüğünü, n: örneklem büyüklüğünü, p: olayın görülme olasılığını, q: 1-p: olayın görülmeme olasılığını, d: kabul edilen \pm örnekleme hata oranını ve $\mathrm{t} \_(\alpha, \mathrm{sd}): \alpha$ anlamlılık düzeyinde, serbestlik derecesine göre $\mathrm{t}$ kritik değerini ifade etmektedir.

Buna göre gerekli örneklem sayısının 103 olduğu tespit edilmiştir. 


\section{BULGULAR}

\subsection{Güvenirlik Katsayısı}

Bu çalışmada güvenirlilik analizinde Croncbach Alfa Katsayısı kullanılmıştır. Alfa katsayısının değerlendirilme aralıkları şu şekilde sınıflandırılmıştır (Kalaycı, 2005: 405)

Tablo 1. Cronbach's Alpha Katsayısı İçin Güvenilirlik Düzeyleri

Cronbach's Alpha katsayısı için güvenirlik düzeyleri

\begin{aligned} & \hline$\alpha<0.50$ Ölçek güvenilir değildir \\ & \hline $0.50<\alpha<0.60$ Ölçek düşük düzeyde güvenilirdir \\ & \hline $0.60<\alpha<0.70$ Ölçek kabul edilebilir düzeyde güvenilirdir \\ & \hline $0.70<\alpha<0.90$ Ölçek iyi düzeyde güvenilirdir \\ & \hline$\alpha>0.90$ Ölçek çok iyi düzeyde güvenilirdir \\ & \hline\end{aligned}

Tablo 2. Cronbach's Alpha Tekniğine İlişkin Çözümleme Sonuçları

\begin{tabular}{lccl}
\hline \multicolumn{1}{c}{ Boyutlar } & $\begin{array}{c}\text { Cronbach's } \\
\text { Alpha } \\
\text { Katsayısı }\end{array}$ & $\begin{array}{c}\text { Madde } \\
\text { Sayısı }\end{array}$ & Güvenirlilik Düzeyi \\
Ekonomi Okuryazarlık Düzeyleri & .96 & 34 & Çok iyi düzeyde güvenilir \\
Ekonomi Bilgisi & .91 & 13 & Çok iyi düzeyde güvenilir \\
Ekonomik Akılcılık & .91 & 9 & Çok iyi düzeyde güvenilir \\
Toplumsal Ekonomik Yansımalar & .92 & 9 & Çok iyi düzeyde güvenilir \\
Bireysel Ekonomi Planlama" & .92 & 3 & Çok iyi düzeyde güvenilir \\
\hline
\end{tabular}

Tablo 2'den de görüldügü üzere, ekonomi okuryazarlık ölçeği ve alt boyutları çok iyi düzeyde güvenilirdir.

\subsection{Normallik Analizi}

Verilerin normal dağılıp dağılmadığının tespit edilmesinde Kolmogorov-Smirnov ve ShapiroWilk değerleri tespit edilmiştir. Kolmogorov-Smirnov ve Shapiro-Wilk değerlerinin 0,05 'ten büyük olması beklenmektedir. Bu koşulun yerine geldiği durumlarda verilerin normal dağılıma sahip olduğu varsayılır. Normallik testi sonucu Tablo 3'te verilmiştir.

Tablo 3. Normallik Test Sonuçları

\begin{tabular}{lcccccc}
\hline & \multicolumn{2}{c}{ Kolmogorov-Smirnov } & \multicolumn{3}{c}{ Shapiro-Wilk } \\
\cline { 2 - 7 } & İstatistik & $\mathbf{d f}$ & $\mathbf{p}$ & İstatistik & $\mathbf{d f}$ & $\mathbf{p}$ \\
\hline Finansal okuryazarlık & .122 & 210 & .000 & .926 & 210 & .000 \\
\hline Ekonomi bilgisi & .100 & 210 & .000 & .950 & 210 & .000 \\
\hline Ekonomik akılcılık & .145 & 210 & .000 & .926 & 210 & .000 \\
\hline $\begin{array}{l}\text { Toplumsal ekonomik } \\
\text { yansımalar }\end{array}$ & .131 & 210 & .000 & .914 & 210 & .000 \\
\hline $\begin{array}{l}\text { Bireysel ekonomi } \\
\text { planlama }\end{array}$ & .184 & 210 & .000 & .877 & 210 & .000 \\
\hline
\end{tabular}

Tablo 3'den de görüleceği üzere, üniversite öğrencilerinin ekonomi okuryazarlık düzeylerini ortaya koyan ifadelerin normal bir dağılım göstermemesinden dolayı bu araştırmada parametrik olmayan test yöntemleri kullanılmıştır. 


\subsection{Katılımclara ait Genel Betimsel İstatistikler}

Araştırmada demografik faktörler olarak; katılımcıların sınıfları, cinsiyetleri, herhangi bir işte çalışıp çalışmadıkları, kredi kartı sahiplik durumu ve lisans eğitimi boyunca alınan dersler olarak belirlenmiştir. Aşağıda katılımcıların söz konusu özelliklerine ilişkin frekans dağılımlarına yer verilmiştir.

Tablo 4. Katılımcılara Ait Demografik Özellikler

\begin{tabular}{lcc}
\hline Cinsiyetiniz & $\mathrm{N}$ & $\%$ \\
\hline Erkek & 59 & 28,1 \\
\hline Kadın & 151 & 71,9 \\
\hline Toplam & 210 & 100,0 \\
\hline Sınıfınız & $\mathrm{N}$ & $\%$ \\
\hline & 57 & 27,1 \\
\hline 1. sınıf & 34 & 16,2 \\
\hline 2. sınıf & 77 & 36,7 \\
\hline 3. sinıf & 42 & 20,0 \\
\hline 4. sınıf & 210 & 100,0 \\
\hline Toplam & $\mathrm{N}$ & $\%$ \\
\hline Herhangi bir işte çalışıyor musunuz? & 12,9 \\
\hline & 27 & 87,1 \\
\hline Evet & 183 & 100,0 \\
\hline Hayır & 210 & \\
\hline Toplam & $\mathrm{N}$ & $\%$ \\
\hline Kredi kartı kullanıyor musunuz? & 46,7 \\
\hline & 98 & 53,3 \\
\hline Evet & 112 & 100,0 \\
\hline Hayır & 210 & \\
\hline Toplam & $\% 2817$
\end{tabular}

Katılımcıların cinsiyet dağılımlarında \%28,1'inin erkek, \%71,9'unun ise kadınlardan oluştuğu görülmektedir. Katılımcıların öğrenim gördükleri sınıf dağılımlarında ise \%27,1'inin 1. Sınıf; $\% 16,2^{\prime} \operatorname{sinin} 2$. Sınıf; \%36,7'sinin 3. Sınıf ve \%20'sinin ise 4 . Sınıfta olduğu ortaya çıkmıştır.

Katılımcıları herhangi bir işte çalışma durumlarına baktığımızda ise büyük çoğunluğun $(\% 87,1)$ herhangi bir yerde çalışmadığı ortaya çıkmıştır. Katılımcıların kredi kartı kullanma durumlarında da benzer şekilde büyük çoğunluğun kredi kartı kullanmadığı ortaya çıkmıştır.

Tablo 5. Lisans Eğitimi Boyunca Alınan Derslere Yönelik Dağılımlar

\begin{tabular}{lc}
\hline & $\mathbf{N}$ \\
\hline Muhasebe-1 & 210 \\
\hline Muhasebe-2 & 137 \\
\hline Maliyet Muhasebesi & 6 \\
\hline Finansal Yönetim & 141 \\
\hline
\end{tabular}

Katılımcıların lisans eğitimi boyunca aldıkları derslere yönelik dağılımlara bakıldığında 210 kişi Muhasebe 1, 137 kişi Muhasebe 2, 6 kişi Maliyet Muhasebesi ve 141 kişi ise Finansal Yönetim dersini aldığını ifade etmiştir. 


\subsection{Ekonomi Okuryazarlık Ölçeğine Yönelik Elde Edilen Betimsel İstatistikler}

Araştırmanın bu kısmında Ekonomi Okuryazarlık ölçeği içerisinde yer alan ifadelerin her birine katılımcların verdikleri cevapların ortalama ve standart sapma değerleri yer almaktadır. Burada elde edilen ortalama değerlerin yorumlanmasında aşağıdaki sınıflama aralıkları baz alınmıştır:

1,00-1,80 aralığında çok düşük;

1,81-2,60 aralığında düşük;

2,61-3,40 aralığında orta;

3,41-4,20 aralığında yüksek ve 4,21-5,00 aralığında çok yüksek düzeyli (Gönen, 2013: 97).

Tablo 6. Ekonomi Okuryazarlık Ölçeğine Yönelik Elde Edilen Sonuçlar

\begin{tabular}{|c|c|c|c|}
\hline & Ort. & $\begin{array}{c}\text { Std. } \\
\text { Sapma }\end{array}$ & $\begin{array}{l}\text { Katılım } \\
\text { Düzeyi }\end{array}$ \\
\hline $\begin{array}{l}\text { Döviz fiyatlarındaki değişimin } \begin{array}{r}\text { ihracat ve } \\
\text { ithalat üzerindeki } \\
\text { yorumlayabilirim. }\end{array} \\
\end{array}$ & 3.39 & .918 & Orta \\
\hline $\begin{array}{l}\text { IMF politikalarının ekonomi üzerindeki } \\
\text { etkisini tartsşabilirim. }\end{array}$ & 2.97 & .835 & Orta \\
\hline $\begin{array}{l}\text { Menkul kıymetler borsasındaki gelişmelerin } \\
\text { ekonomiye etkisini anlayabilirim. }\end{array}$ & 3.22 & .950 & Orta \\
\hline $\begin{array}{l}\text { Uluslararası ekonomik kaynakların piyasaya } \\
\text { etkisini anlayabilirim. }\end{array}$ & 3.40 & .929 & Orta \\
\hline $\begin{array}{l}\text { Ulusal finansal kaynakların ekonomiye } \\
\text { etkisini anlayabilirim. }\end{array}$ & 3.40 & .913 & Orta \\
\hline $\begin{array}{l}\text { Enflasyon oranlarındaki değişmenin ne ifade } \\
\text { ettiğini anlayabilirim. }\end{array}$ & 3.52 & 1.008 & Yüksek \\
\hline $\begin{array}{l}\text { Dış ekonomik gelişmelerin ülke ekonomisine } \\
\text { yansımalarını yorumlayabilirim. }\end{array}$ & 3.46 & .988 & Yüksek \\
\hline $\begin{array}{lll}\begin{array}{l}\text { Faiz oranlarının piyasaya } \\
\text { anlayabilirim. }\end{array} & \text { etkisini } \\
\end{array}$ & 3.60 & .902 & Yüksek \\
\hline $\begin{array}{lll}\text { Ekonomik politikaların fayda } & \text { ve } \\
\text { maliyetlerini değerlendirebilirim. } & \\
\end{array}$ & 3.25 & .889 & Orta \\
\hline $\begin{array}{l}\text { Küçük, orta ve büyük ölçekli işletmelerin } \\
\text { (KOBİ) ekonomik rollerini anlayabilirim. }\end{array}$ & 3.36 & .969 & Orta \\
\hline $\begin{array}{l}\text { Döviz ve altın fiyatlarında meydana gelen } \\
\text { değişmenin nedenlerini yorumlayabilirim. }\end{array}$ & 3.48 & .959 & Yüksek \\
\hline $\begin{array}{l}\text { Kamu, özel ve sivil toplum kuruluşlarının } \\
\text { ekonomik rollerini tanımlayabilirim. }\end{array}$ & 3.34 & .884 & Orta \\
\hline $\begin{array}{l}\text { Gelir dağılımı-ekonomi } \\
\text { anlayabilirim. }\end{array}$ & 3.54 & .842 & Yüksek \\
\hline $\begin{array}{lcc}\text { Ekonomik tercihlerimin fayda } & \text { ve } \\
\text { maliyetlerini karşılaştırabilirim. } & \end{array}$ & 3.48 & .974 & Yüksek \\
\hline $\begin{array}{l}\text { Parasal kaynaklarımı değerlendirerek akılcı } \\
\text { (rasyonel) tercihler yapabilirim. }\end{array}$ & 3.51 & .984 & Yüksek \\
\hline $\begin{array}{l}\text { Sunulan hizmetleri ekonomik açıdan } \\
\text { değerlendirebilirim. }\end{array}$ & 3.68 & .902 & Yüksek \\
\hline $\begin{array}{l}\text { Kar ve maliyetler arasındaki fark } 1 \\
\text { anlayabilirim. }\end{array}$ & 3.75 & .926 & Yüksek \\
\hline
\end{tabular}




\begin{tabular}{|c|c|c|c|}
\hline $\begin{array}{l}\text { Genel tüketim harcamalarımı gelirime göre } \\
\text { düzenleyebilirim. }\end{array}$ & 3.69 & 1.135 & Yüksek \\
\hline $\begin{array}{l}\text { Bireylerin davranışlarını etkileyen ekonomik } \\
\text { unsurları algılayabilirim. }\end{array}$ & 3.66 & 1.020 & Yüksek \\
\hline $\begin{array}{l}\text { Üretici ile tüketici arasındaki etkileşimin } \\
\text { fiyatlara nasıl yansıdığını anlayabilirim. }\end{array}$ & 3.76 & .955 & Yüksek \\
\hline $\begin{array}{l}\text { Malın azalmasının ve fazlalaşmasının piyasa } \\
\text { fiyatlarına etkisini yorumlayabilirim. }\end{array}$ & 3.69 & 1.009 & Yüksek \\
\hline $\begin{array}{l}\text { Arz-talep dengesizliklerinin fiyatlara nasıl } \\
\text { yansıdığını anlayabilirim. }\end{array}$ & 3.69 & .951 & Yüksek \\
\hline $\begin{array}{l}\text { Tüketeceğim ürüne karar verirken fiyat- } \\
\text { fayda ilişkisini göz önünde bulundururum. }\end{array}$ & 3.81 & 1.021 & Yüksek \\
\hline $\begin{array}{lll}\begin{array}{l}\text { Rekabetin } \\
\text { anlayabilirim. }\end{array} & \text { ekonomik } & \text { sonuçlarını } \\
\end{array}$ & 3.67 & .985 & Yüksek \\
\hline $\begin{array}{l}\text { Reklam harcamalarının } \\
\text { katkılarını yorumlayabilirim. }\end{array}$ & 3.61 & 1.067 & Yüksek \\
\hline $\begin{array}{l}\text { Tercih edeceğim ürüne karar verirken } \\
\text { ihtiyacımı göz önünde bulundururum. }\end{array}$ & 3.92 & 1.100 & Yüksek \\
\hline $\begin{array}{lll}\begin{array}{l}\text { Rekabetin } \\
\text { anlayabilirim. }\end{array} & \text { ekonomik } & \text { sonuçlarını }\end{array}$ & 3.63 & .951 & Yüksek \\
\hline $\begin{array}{l}\text { Bir malın fiyatı aşıı yükselirse yerine aynı } \\
\text { faydayı sağlayan daha düşük fiyatlısını } \\
\text { alırım. }\end{array}$ & 3.93 & 1.080 & Yüksek \\
\hline $\begin{array}{l}\text { Ürün satın alırken marka yerine kalitesine } \\
\text { bakarım. }\end{array}$ & 3.93 & 1.062 & Yüksek \\
\hline $\begin{array}{l}\text { Ürünlerin tüketicilere ulaşım sürecinin } \\
\text { fiyatlara nasıl yansıdığını anlayabilirim. }\end{array}$ & 3.80 & .979 & Yüksek \\
\hline $\begin{array}{l}\text { Ekonomik krizlerin işsizlik üzerinde } \\
\text { yarattığı etkileri yorumlayabilirim. }\end{array}$ & 3.78 & 1.036 & Yüksek \\
\hline $\begin{array}{l}\text { Kredi kullanırken gelir-gider dengemi } \\
\text { sağlayabilirim. }\end{array}$ & 3.55 & 1.294 & Yüksek \\
\hline $\begin{array}{l}\text { Kredi kartı kullanırken ödeme gücüme göre } \\
\text { harcama yaparım. }\end{array}$ & 3.76 & 1.283 & Yüksek \\
\hline $\begin{array}{l}\text { Taksitlendirme yaparken gelirimi göz } \\
\text { önünde bulundururum. }\end{array}$ & 3.89 & 1.250 & Yüksek \\
\hline
\end{tabular}

Tablo 6 incelendiğinde katılımcıların ekonomi okuryazarlık düzeyini ortaya koyan ifadelerden en yüksek düzeyli katılımın "bir malın fiyatı aşırı yükselirse yerine aynı faydayı sağlayan daha düşük fiyatlısını alırım" ve "ürün satın alırken marka yerine kalitesine bakarım" ifadelerine ait olduğu ortaya çıkmıştır. Bu kısımda en düşük düzeyli katılımın ise "IMF politikalarının ekonomi üzerindeki etkisini tartışabilirim" ifadesine ait olduğu ortaya çıkmıştır. 
Tablo 7. Tüm Boyutların Ortalama ve Standart Sapma Sonuçları

\begin{tabular}{lll}
\hline & Ort. & SS \\
\hline Finansal okuryazarlı & 3.59 & .638 \\
\hline Ekonomi bilgisi & 3.38 & .639 \\
\hline Ekonomik akılcılık & 3.66 & .759 \\
\hline Toplumsal ekonomik yansimalar & 3.79 & .808 \\
\hline Bireysel ekonomi planlama & 3.73 & 1.182 \\
\hline
\end{tabular}

Tablo 7'ye bakıldığında katılımcıların ekonomi okuryazarlık ölçeğinin geneline 3,59'luk düzeyde bir katılım sağladığı ortaya çıkmıştır. Bu kısımda en yüksek düzeyli katılımın toplumsal ekonomik yansımalar boyutuna, en düşük katılımın ise ekonomi bilgisi boyutuna ait olduğu ortaya çıkmıştır.

\subsection{Hipotezlerin Test Edilmesi}

Araştırmanın bu kısmında, katılımcıların ekonomi okuryazarlık düzeyleri ile cinsiyet, sınıf, herhangi bir işte çalışma durumu ve kredi kartı kullanma durumu arasında anlamlı bir farklılığın olup olmadığına yönelik sonuçlar yer almaktadır.

Buna göre araştırmaya katılan öğrencilerin ekonomi okuryazarlık düzeylerinin karşılaştırılmasında iki seçenekli sorular için Mann-Whitney U testi, ikiden fazla seçeneğe sahip sorularda Kruskal-Wallis H testi uygulanmıştır. Bu araştırmada kullanılan Mann-Whitney U ve Kruskal-Wallis $\mathrm{H}$ testinin değerlendirilmesinde anlamlılık düzeyi 0,05 olarak kabul edilmiştir.

$H_{1}$ : Üniversite öğrencilerinin ekonomi okuryazarlık seviyeleri cinsiyetlerine göre anlamlı bir şekilde farklılık göstermektedir.

Katılımcların cinsiyetleri ile ekonomi okuryazarlık düzeyleri arasında anlamlı bir farklılık olmadığı ortaya çıkmış olup H1 hipotezi reddedilmiştir (Tablo 8).

Tablo 8. Cinsiyete Göre Ekonomi Okuryazarlık Düzeyinin Karşılaştırılması

\begin{tabular}{|c|c|c|c|c|c|c|}
\hline & Cinsiyetiniz & $\mathbf{N}$ & $\begin{array}{c}\text { Siralı } \\
\text { Ortalama }\end{array}$ & $\begin{array}{c}\text { Siralar } \\
\text { Toplamı }\end{array}$ & $\begin{array}{c}\text { Mann- } \\
\text { Whitney U }\end{array}$ & $p$ \\
\hline \multirow{3}{*}{$\begin{array}{l}\text { Finansal } \\
\text { okuryazarlık }\end{array}$} & Erkek & 59 & 113,59 & 6702,00 & \multirow{3}{*}{3977,000} & \multirow[t]{3}{*}{,23 } \\
\hline & Kadın & 151 & 102,34 & 15453,00 & & \\
\hline & Toplam & 210 & & & & \\
\hline \multirow{3}{*}{$\begin{array}{l}\text { Ekonomi } \\
\text { bilgisi }\end{array}$} & Erkek & 59 & 116,98 & 6902,00 & \multirow[t]{3}{*}{3777,000} & \multirow[t]{3}{*}{,09 } \\
\hline & Kadın & 151 & 101,01 & 15253,00 & & \\
\hline & Toplam & 210 & & & & \\
\hline \multirow{3}{*}{$\begin{array}{l}\text { Ekonomik } \\
\text { akılcılık }\end{array}$} & Erkek & 59 & 111,48 & 6577,50 & \multirow[t]{3}{*}{4101,500} & \multirow[t]{3}{*}{37} \\
\hline & Kadın & 151 & 103,16 & 15577,50 & & \\
\hline & Toplam & 210 & & & & \\
\hline \multirow{3}{*}{$\begin{array}{l}\text { Toplumsal } \\
\text { ekonomik } \\
\text { yansımalar }\end{array}$} & Erkek & 59 & 116,19 & 6855,00 & \multirow[t]{3}{*}{3824,000} & \multirow[t]{3}{*}{,11 } \\
\hline & Kadın & 151 & 101,32 & 15300,00 & & \\
\hline & Toplam & 210 & & & & \\
\hline \multirow{3}{*}{$\begin{array}{l}\text { Bireysel } \\
\text { ekonomi } \\
\text { planlama }\end{array}$} & Erkek & 59 & 100,63 & 5937,00 & \multirow[t]{3}{*}{4167,000} & \multirow[t]{3}{*}{46} \\
\hline & Kadın & 151 & 107,40 & 16218,00 & & \\
\hline & Toplam & 210 & & & & \\
\hline
\end{tabular}

$\mathrm{H}_{2}$ : Üniversite öğrencilerinin ekonomi okuryazarlık seviyeleri sınıflarına göre anlamlı bir şekilde farklılık göstermektedir. 
Katılımcıların öğrenim gördükleri sınıfları ile ekonomi okuryazarlık düzeyleri arasında anlamlı bir farklılık olmadığı ortaya çıkmış olup H2 hipotezi reddedilmiştir. Bu kısımda katılımcıların ekonomi bilgisi alt boyutunda yer alan ifadelerde ise sınıflarına göre farklılaştı̆̆ı ortaya çıkmıştır. Söz konusu farklılığın hangi gruplar arasında olduğunun tespit edilmesi amaciyla Games Howell çoklu karşılaştırma testine başvurulmuş olup teste ilişkin sonuçlar aşağıdaki Tablo 9'da gösterilmiştir.

Tablo 9. Öğrenim Görülen Sınıfa Göre Ekonomi Okuryazarlık Düzeyinin Karşılaştırılması

\begin{tabular}{|c|c|c|c|c|c|}
\hline & Sinifiniz & $\mathbf{N}$ & $\begin{array}{c}\text { Siralı } \\
\text { Ortalama }\end{array}$ & $\begin{array}{l}\text { Kruskal- } \\
\text { Wallis H }\end{array}$ & $\mathrm{p}$ \\
\hline \multirow[t]{5}{*}{ Finansal okuryazarlık } & 1. sinif & 57 & 95,10 & \multirow[t]{5}{*}{5,627} & \multirow[t]{5}{*}{13} \\
\hline & 2. sinif & 34 & 104,75 & & \\
\hline & 3. sinif & 77 & 103,48 & & \\
\hline & 4. sinif & 42 & 123,93 & & \\
\hline & Toplam & 210 & & & \\
\hline \multirow[t]{5}{*}{ Ekonomi bilgisi } & 1. sinif & 57 & 85,68 & \multirow[t]{5}{*}{13,630} & \multirow[t]{5}{*}{, 00} \\
\hline & 2. sinif & 34 & 103,22 & & \\
\hline & 3. sinif & 77 & 107,24 & & \\
\hline & 4. sinif & 42 & 131,05 & & \\
\hline & Toplam & 210 & & & \\
\hline \multirow[t]{5}{*}{ Ekonomik akılcılık } & 1. sinif & 57 & 101,02 & \multirow[t]{5}{*}{6,107} & \multirow[t]{5}{*}{11} \\
\hline & 2. sinif & 34 & 108,34 & & \\
\hline & 3. sinif & 77 & 97,08 & & \\
\hline & 4. sinif & 42 & 124,73 & & \\
\hline & Toplam & 210 & & & \\
\hline \multirow{5}{*}{$\begin{array}{l}\text { Toplumsal ekonomik } \\
\text { yansımalar }\end{array}$} & 1. sinif & 57 & 106,26 & \multirow[t]{5}{*}{611} & \multirow[t]{5}{*}{89} \\
\hline & 2. sinif & 34 & 101,66 & & \\
\hline & 3. sinif & 77 & 103,48 & & \\
\hline & 4. sinif & 42 & 111,27 & & \\
\hline & Toplam & 210 & & & \\
\hline \multirow{5}{*}{$\begin{array}{l}\text { Bireysel ekonomi } \\
\text { planlama }\end{array}$} & 1. sinif & 57 & 109,16 & \multirow[t]{5}{*}{2,013} & \multirow[t]{5}{*}{, 57} \\
\hline & 2. sinif & 34 & 98,06 & & \\
\hline & 3. sinif & 77 & 101,29 & & \\
\hline & 4. sinif & 42 & 114,27 & & \\
\hline & Toplam & 210 & & & \\
\hline
\end{tabular}

Tablo 10. Sınıf Değişkenine Göre Ekonomi Bilgisinin Çoklu Karşılaştırma Test Sonuçları

\begin{tabular}{|c|c|c|c|}
\hline \multicolumn{4}{|c|}{ Bağımlı Değişken: Ekonomi bilgisi } \\
\hline \multicolumn{4}{|c|}{ Games-Howell } \\
\hline Sinıf & Alt Gruplar & Ortalamalar Fark1 & $\mathbf{p}$ \\
\hline \multirow[t]{3}{*}{ 1. sinif } & 2. sinif & 172 & 484 \\
\hline & 3. sinif & 154 & 490 \\
\hline & 4. sinif & $403^{*}$ & 014 \\
\hline
\end{tabular}


Katılımcıların sınıfları ile ekonomi bilgisinin çoklu karşılaştırma test sonucuna baktığımızda 1 . Sınıfta olanların ekonomi bilgisine yönelik görüşleri ile 4 . Sınıftakilerin görüşleri arasında 0,05 düzeyinde anlamlı bir farklılık olduğu ortaya çıkmıştır (Tablo 10).

$\mathrm{H}_{3}$ : Üniversite öğrencilerinin ekonomi okuryazarlık seviyeleri herhangi bir işte çalışma durumuna göre anlamlı bir şekilde farklılık göstermektedir.

Katılımcların herhangi bir işe çalışma durumu ile ekonomi okuryazarlık düzeyleri arasında anlamlı bir farklılık olmadığı ortaya çıkmış olup, H3 hipotezi reddedilmiştir (Tablo 11).

Tablo 11. Herhangi Bir İşte Çalışma Durumuna Göre Ekonomi Okuryazarlık Düzeyinin Karşılaştırılması

\begin{tabular}{|c|c|c|c|c|c|c|}
\hline & $\begin{array}{l}\text { Herhangi Bir İşte } \\
\text { Çalışıyor musunuz? }\end{array}$ & $\mathbf{N}$ & $\begin{array}{c}\text { Siralı } \\
\text { Ortalama }\end{array}$ & $\begin{array}{l}\text { Siralar } \\
\text { Toplamı }\end{array}$ & $\begin{array}{c}\text { Mann- } \\
\text { Whitney } \\
\text { U }\end{array}$ & $p$ \\
\hline \multirow{5}{*}{$\begin{array}{l}\text { Finansal } \\
\text { okuryazarlık }\end{array}$} & Evet & 27 & 104,59 & 2824,00 & \multirow[t]{5}{*}{2446,000} & \multirow[t]{5}{*}{,93 } \\
\hline & \multirow[t]{2}{*}{ Hayır } & 18 & 105,63 & 19331,00 & & \\
\hline & & 3 & & & & \\
\hline & \multirow[t]{2}{*}{ Toplam } & 21 & & & & \\
\hline & & 0 & & & & \\
\hline \multirow{5}{*}{$\begin{array}{l}\text { Ekonomi } \\
\text { bilgisi }\end{array}$} & Evet & 27 & 102,98 & 2780,50 & \multirow[t]{5}{*}{2402,500} & \multirow[t]{5}{*}{,82 } \\
\hline & \multirow{2}{*}{ Hayır } & 18 & 105,87 & 19374,50 & & \\
\hline & & 3 & & & & \\
\hline & \multirow[t]{2}{*}{ Toplam } & 21 & & & & \\
\hline & & 0 & & & & \\
\hline \multirow{5}{*}{$\begin{array}{l}\text { Ekonomik } \\
\text { akılcılık }\end{array}$} & Evet & 27 & 97,96 & 2645,00 & \multirow[t]{5}{*}{2267,000} & \multirow[t]{5}{*}{ 49 } \\
\hline & \multirow{2}{*}{ Hayır } & 18 & 106,61 & 19510,00 & & \\
\hline & & 3 & & & & \\
\hline & \multirow[t]{2}{*}{ Toplam } & 21 & & & & \\
\hline & & 0 & & & & \\
\hline \multirow{5}{*}{$\begin{array}{l}\text { Toplumsal } \\
\text { ekonomik } \\
\text { yansimalar }\end{array}$} & Evet & 27 & 96,70 & 2611,00 & \multirow[t]{5}{*}{2233,000} & ,42 \\
\hline & \multirow[t]{2}{*}{ Hayır } & 18 & 106,80 & 19544,00 & & \\
\hline & & 3 & & & & \\
\hline & \multirow[t]{2}{*}{ Toplam } & 21 & & & & \\
\hline & & 0 & & & & \\
\hline \multirow{5}{*}{$\begin{array}{l}\text { Bireysel } \\
\text { ekonomi } \\
\text { planlama }\end{array}$} & Evet & 27 & 115,61 & 3121,50 & \multirow[t]{5}{*}{2197,500} & \multirow[t]{5}{*}{,35 } \\
\hline & \multirow[t]{2}{*}{ Hayır } & 18 & 104,01 & 19033,50 & & \\
\hline & & 3 & & & & \\
\hline & \multirow[t]{2}{*}{ Toplam } & 21 & & & & \\
\hline & & 0 & & & & \\
\hline
\end{tabular}

$\mathrm{H}_{4}$ : Üniversite öğrencilerinin ekonomi okuryazarlık seviyeleri kredi kartı kullanma durumuna göre anlamlı bir şekilde farklılık göstermektedir.

Katılımcıların kredi kartı kullanma durumları ile ekonomi okuryazarlık düzeyleri arasında anlamlı bir farklılık olmadığı ortaya çıkmış olup H4 hipotezi reddedilmiştir (Tablo 12). 
Tablo 12. Kredi Kartı Kullanma Durumuna Göre Ekonomi Okuryazarlık Düzeyinin Karşılaştırılması

\begin{tabular}{|c|c|c|c|c|c|c|}
\hline & $\begin{array}{l}\text { Kredi Kartı } \\
\text { Kullaniyor } \\
\text { musunuz? }\end{array}$ & $\mathbf{N}$ & $\begin{array}{c}\text { Siralı } \\
\text { Ortalama }\end{array}$ & $\begin{array}{c}\text { Siralar } \\
\text { Toplamı }\end{array}$ & $\begin{array}{c}\text { Mann- } \\
\text { Whitney } \\
\text { U }\end{array}$ & $\mathrm{p}$ \\
\hline \multirow{3}{*}{$\begin{array}{l}\text { Finansal } \\
\text { okuryazarlık }\end{array}$} & Evet & 98 & 107,23 & 10508,50 & 5318,500 & 70 \\
\hline & Hayır & 112 & 103,99 & 11646,50 & & \\
\hline & Toplam & 210 & & & & \\
\hline \multirow{3}{*}{$\begin{array}{l}\text { Ekonomi } \\
\text { bilgisi }\end{array}$} & Evet & 98 & 108,43 & 10626,00 & 5201,000 &, 51 \\
\hline & Hayır & 112 & 102,94 & 11529,00 & & \\
\hline & Toplam & 210 & & & & \\
\hline \multirow{3}{*}{$\begin{array}{l}\text { Ekonomik } \\
\text { akılcıllk }\end{array}$} & Evet & 98 & 102,47 & 10042,50 & 5191,500 &, 50 \\
\hline & Hayır & 112 & 108,15 & 12112,50 & & \\
\hline & Toplam & 210 & & & & \\
\hline \multirow{3}{*}{$\begin{array}{l}\text { Toplumsal } \\
\text { ekonomik } \\
\text { yansımalar }\end{array}$} & Evet & 98 & 105,15 & 10304,50 & 5453,500 & ,94 \\
\hline & Hayır & 112 & 105,81 & 11850,50 & & \\
\hline & Toplam & 210 & & & & \\
\hline \multirow{3}{*}{$\begin{array}{l}\text { Bireysel } \\
\text { ekonomi } \\
\text { planlama }\end{array}$} & Evet & 98 & 108,10 & 10593,50 & 5233,500 &, 56 \\
\hline & Hayır & 112 & 103,23 & 11561,50 & & \\
\hline & Toplam & 210 & & & & \\
\hline
\end{tabular}

\section{SONUÇ VE ÖNERILLER}

Bu araştırma, Nevşehir Hacı Bektaş Veli Üniversitesi İ̈BF'de ekonomi eğitimi alan Bankacılık Bölümü öğrencilerinin ekonomi okuryazarlık düzeylerinin incelenmesi amacıyla gerçekleştirilmiştir. Araştırmada ekonomi okuryazarlık düzeyinin tespitinde anket yöntemine başvurulmuştur. Anket sonucunda aşağıdaki sonuçlara ulaşılmıştır:

Araştırmada katılımcıların ekonomi okuryazarlık düzeyini ortaya koyan ifadelerden en yüksek düzeyli katılımı "bir malın fiyatı aşırı yükselirse yerine aynı faydayı sağlayan daha düşük fiyatlısını alırım" ve "ürün satın alırken marka yerine kalitesine bakarım" ifadesi ile; en düşük katılımı ise "IMF politikalarının ekonomi üzerindeki etkisini tartışabilirim" ifadesi ile sağladığı ortaya çıkmıştır.

$\checkmark$ Katılımcıların ekonomi okuryazarlık düzeylerini ortaya koyan ifadelere genel olarak 3,59'luk düzeyde katılım sağladıkları ortaya çıkmıştır. Bu kısımda en yüksek düzeyli katılım, "toplumsal ekonomik yansımalar" boyutunda; en düşük katılım ise "ekonomi bilgisi" boyutunda ortaya çıkmıştır.

$\checkmark$ Araştırmada katılımcıların ekonomi okuryazarlık düzeyleri ile bazı demografik özellikler arasında anlamlı bir farklılık olup olmadığı da ortaya konulmuştur. Araştırmada yapılan analiz sonucunda, katılımcıların cinsiyetleri ile ekonomi okuryazarlık düzeyleri arasında anlamlı bir farklılık olmadığı ortaya çıkmıştır.

$\checkmark$ Araştırmada elde edilen bir diğer sonuç ise, katılımcıların sınıfları ile ekonomi okuryazarlık düzeyleri arasında anlamlı bir farklılık olmadığıdır. Ancak, katılımcıların ekonomi bilgisi alt boyutunda yer alan ifadelerde sınıf değişkenine göre farklılaşma olduğu ve bu farklılıkta 1 . sınıfta olanların ekonomi bilgisine yönelik görüşleri ile 4 . sınıftakilerin görüşleri arasında 0,05 düzeyinde anlamlı bir farklılık olduğu ortaya çıkmıştır. Bu farklılığın sınıf düzeyi arttıkça öğrencilerin aldıkları ekonomi derslerinin artmasından kaynaklandığı düşünülmektedir. 
Son olarak, katılımcıların kredi kartı kullanma durumları ile ekonomi okuryazarlık düzeyleri arasında anlamlı bir farklılık olmadığı ortaya çıkmıştır.

Bu araştırmada yapılan literatür incelemeleri ve anket uygulaması sonucunda aşağıdaki önerilere yer verilmiştir:

$\checkmark$ Nevşehir Hacı Bektaş Veli Üniversitesi İ̈BF'de ekonomi eğitimi alan Bankacılık bölümü öğrencileri üzerinde yapılan bu çalışma, farklı örneklem kitleleri üzerinde yapılabilir.

$\checkmark$ Araştırmada katılımcıların ekonomi okuryazarlık düzeylerini ortaya koymak amacıyla nicel araştırma yöntemine başvurulmuştur. Gelecekteki araştırmalarda odak grup görüşmeleri ve mülakat yönteminin yer aldığı nitel analiz yöntemlerine başvurulabilir. Bu kapsamda katılımcı görüşlerini ortaya koyan ifadeler içerik analizi yöntemiyle incelenebilir.

$\checkmark$ Araştırmada katılımcıların ekonomi okuryazarlık düzeylerinin karşılaştırılmasında cinsiyet, sınıf, herhangi bir işte çalışma durumu ve kredi kartı kullanma durumu değişkenleri baz alınmıştır. Gelecekteki araştırmalarda katılımcıların yaşları ve diğer özellikleri baz alınarak karşılaştırma çalışmaları yapılabilir.

$\checkmark$ Katılımcıların ekonomi okuryazarlık düzeyleri ile okuldaki başarı durumları arasındaki ilişkiyi ortaya koyacak yeni çalışmalar yapılabilir.

$\checkmark$ Ekonomi okuryazarlık düzeylerinin yüksek olmasının kaynakların etkin bir şekilde kullanılmasına sağlayacağı katkı düşünüldüğünde, ekonomi okuryazarlık düzeyinin artırılması için daha ilkokul düzeyinden başlanarak ders müfredatlarına eklenmesi uygun olacaktır.

\section{KAYNAKÇA}

Akhan, N.E. (2013). Adım Adım Ekonomi Okuryazarlığı: Sosyal Bilgiler Dersleri İçin Alternatif Yolları. Adıyaman Üniversitesi Sosyal Bilimler Enstitüsü Dergisi. 6 (14), 2-36.

Aldemir, A. (2003). Bilgiye Erişim Yeni Yaklaşım: Bilgi Okuryazarlığı. ÜNAK 2003: Bilgiye Erişimde Değişen Yollar ve II. Tibbi Bilgi Yönetimi ve Teknolojileri Sempozyumu, Sakarya: Sakarya Üniversitesi, 271-281.

Barış, S. ve Şeker, H. (2017). Ekonomi Okuryazarlığı: Amasya Üniversitesi Bir Araştırma. Finans Politik \& Ekonomik Yorumlar, 54 (624), 79-93.

Bilgen, U. Ve C. Çılbant, C. (2015). Manisa Gördes'de 2008-2014 Yılları Arasında Tarımsal ÜretimFiyat İlişkisi. Yönetim ve Ekonomi, 22 (2), 685-697.

Çil Koçyiğit, S., Şeremet G. G. ve Altunay R. (2018). Ekonomi Bilimlerinde Güncel Akademik Çalışmalar. Unvan, Y.A. (Ed.), Să̆glk Yönetimi Bölümü ve İşletme Bölümü Öğrencilerinin Ekonomi Okuryazarlığı Üzerine Bir Araştırma: Ankara Hacı Bayram Veli Üniversitesi Örneği (225-243). Ankara: Gece Kitaplığı.

Dilek S., Küçük O. ve Eleren A. (2016). Kastamonu Öğrencilerinin Ekonomi Okuryazarlığı. İnsan ve Toplum Bilimleri Araştırmaları Dergisi, 5 (7), 1865-1878.

Gerek, D. ve Kurt A. A. (2011). Ekonomi Okuryazarlığı Ölçeğinin Geçerlilik Ve Güvenirlik Çalışması. Uludă̆ Üniversitesi İktisadi ve İdari Bilimler Fakültesi Dergisi, 30 (1), 59-73.

Gönen, B. (2013), Stratejik Yönetim Dersinin Öğrencilere İş Dünyasında Gerekli Nitelikleri Kazandırma Düzeyi: Ankara Üniversitesinde Bir Araştırma. (Yüksek Lisans Tezi), Atılım Üniversitesi / Sosyal Bilimler Enstitüsü, Ankara. 
Hayta, N. ve Akhan, N. E. (2014). İlköğretim Sosyal Bilgileri Derslerinde Ekonomi Okuryazarlı̆̆ının Geliştirilmesi. TSA, 18 (1), 205-230.

Kalaycı, Ş. (2005). SPSS Uygulamalı Çok Değişkenli İstatistik Teknikleri. Ankara: Asil Yayın Dağıtım.

Lusardi, A. ve Mitchell, O.S. (2011). "Financial Literacy Around The World: An Overview”. NBER Working Paper, 17107, http://www.nber.org/papers/w17107 (Erişim Tarihi: 15.01.2020).

Mercan, N., Oyur, E., Altınay, A. ve Aksanyar, Y. (2012). Ekonomi Okur Yazarlığına Ampirik Bir Araştırma. Ekonomi Bilimleri Dergisi, 4 (2), 109-118.

Özgür Güler, E. ve Veysikarani D. (2019). Ekonomi Okuryazarlığı Üzerine Ampirik Bir Araştırma. Ç.Ü. Sosyal Bilimler Enstitüsü Dergisi, 28 (1), 126-141.

Şantaş, F. ve Demirgil, B. (2015). Ekonomi Okuryazarlığı Düzeyinin Tespitine İlişkin Bir Araştırma. Akademik Bakış Dergisi, 48, 46-60.

Ünal, S., Söylemez, C. ve Düger Y.S. (2015). Ekonomi Okuryazarlığı Ve Kredi Kartı Tutumunun Rasyonel Kredi Kartı Kullanımına Etkisi: Dumlupınar Üniversitesi Tavşanlı MYO Örneği. Eskişehir Osmangazi Üniversitesi İIBF Dergisi, 10 (1), 31-52.

Yamane, T. (2001). Temel Örnekleme Yöntemleri. (Çev: A. Esin, Bakır, M. A., Aydın, C. ve Gürbüzsel, E.), İstanbul: Literatür Yayınları.

Yıldırım, G. (2017). Çocuklar İçin Yaygın Eğitim Kapsamında Yürütülen Ekonomi Eğitimi Çalışmalarının İncelenmesi. Uşak Üniversitesi Sosyal Bilimler Dergisi, 10 (2), 104-124.

Yıldırım, G. ve Öztürk, C. (2017). An Investigation of the Views of Field Experts and Teachers Related to Economic Litteracy and its Education. Erciyes Journal of Education, 1 (2), 1-22.

Yıldız, A. (2004). Türkiye'deki Yetişkin Eğitimi Araştırmalarına Toplu Bakış. Ankara Üniversitesi Eğitim Bilimleri Fakültesi Dergisi, 37 (1), 78-97. 